\title{
Thrombosis of abdominal aorta precipitating fatal subarachnoid haemorrhage
}

\author{
Arul Bala, ${ }^{1}$ Sathyan Gnanalingham, ${ }^{1}$ Kanna Gnanalingham²
}

${ }^{1}$ Neurosurgery, Salford Royal NHS Foundation Trust, Salford, UK

${ }^{2}$ Central Manchester University Hospitals NHS Foundation Trust, Manchester, UK

\section{Correspondence to} Mr Kanna Gnanalingham, kannagnanalingham@gmail. com

Accepted 23 January 2019

\section{Check for updates}

(c) BMJ Publishing Group Limited 2019. No commercial re-use. See rights and permissions. Published by BMJ.

To cite: Bala $A$,

Gnanalingham $S$

Gnanalingham K. BMJ Case

Rep 2019;12:e227323.

doi:10.1136/bcr-2018-

227323

\section{DESCRIPTION}

A 59-year-old woman was admitted with rapidly progressive leg weakness and back pain following exertion. She had been moving furniture 12 hours previously when she experienced sudden back pain. Her medical history included an aorto-bifemoral graft, heavy smoking, hypertension and excessive alcohol use.

On examination, she was severely hypertensive with a blood pressure of $220 / 130 \mathrm{~mm} \mathrm{Hg}$. She was alert and oriented and had a paraparesis affecting her lower limbs with Medical Research Council Muscle scale (MRC) grade 0 power on the right and grade $0-3$ power on the left, with absent reflexes bilaterally. There was a complete sensory level at T10 and she could not feel the urinary catheter. Her lower extremities were mottled, cold to mid-thigh level and there were no peripheral arterial pulses palpable in her lower limbs.

Prior to transfer for a magnetic resonance scan of spine the patient suffered a grand mal seizure. Her postictal conscious level remained low (ie, Glasgow Coma Scale, GCS of 10; E3 V1 M6), requiring ventilation for respiratory support. Her pupils were $3 \mathrm{~mm}$ and non-reactive.

An urgent contrasted CT scan of abdomen revealed complete occlusion of the infra-renal aorta extending into both common iliac grafts (figure 1A). A CT brain scan revealed acute subarachnoid haemorrhage $(\mathrm{SAH})$ in the interhemispheric and left sylvian fissures (figure 1B). CT angiogram of brain revealed a $9 \mathrm{~mm}$ cerebral aneurysm at the right anterior cerebral artery (ie, at A1/A2 junction) and a $3 \mathrm{~mm}$ right pericallosal artery aneurysms (figure 1C).
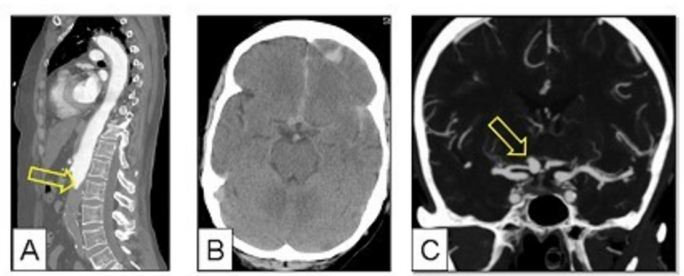

Figure 1 (A) Sagittal reconstruction of the CT angiogram of the abdomen showing lack of contrast flow below the infra-renal aorta. An arrow in this figure shows occlusion of infra-renal aorta. (B) Non-contrasted CT brain scan demonstrates subarachnoid haemorrhage within the interhemispheric fissure. (C) CT angiogram identified an aneurysm of the right anterior cerebral artery. An arrow in this figure shows berry aneurysm.
She was transferred into intensive care but failed to make any neurological improvement and was palliated.

$\mathrm{SAH}$ is a relatively rare cause of haemorrhagic stroke and is typically due to rupture of intracerebral berry aneurysms. SAH affects 5-7 per 100000 of the population and risk factors include female sex, smoking, hypertension, drug (eg, cocaine) and excessive alcohol intake. ${ }^{1}$

This patient was initially suspected to have developed paraparesis secondary to Cauda Equina syndrome, where there is compression of lumbar nerve roots in the spinal canal typically due to a large lumbar disc prolapse. However, her clinical signs (eg, lack of lower limb arterial pulses) and the rapid onset of symptoms suggested an acute vascular event. Furthermore, the patient was at risk of abdominal aortic thrombus due to the pre-existing vascular graft, smoker status and hypertension. The acute occlusion of the distal aorta and the subsequent systemic hypertension, in combination with the occult intracranial aneurysms is likely to have contributed to the fatal SAH. ${ }^{1}$

It is important to consider dual pathologies in patients with such complex presentations.

\section{Learning points}

Acute bilateral leg weakness can be due to sudden loss of blood supply.

- Acute thrombosis of aorta can lead to hypertension with risk of rupture of incidental intracranial aneurysms.

Contributors AB: Drafted the manuscript. SG: Reviewed and revised manuscript. KG: Consultant overseeing neurosurgical care of patient and revised manuscript.

Funding The authors have not declared a specific grant for this research from any funding agency in the public, commercial or not-for-profit sectors.

Competing interests None declared.

Patient consent for publication Next of kin consent obtained. Provenance and peer review Not commissioned; externally peer reviewed.

\section{REFERENCE}

1 Wang GX, Wen L, Yang L, et al. Risk Factors for the Rupture of Intracranial Aneurysms Using Computed Tomography Angiography. World Neurosurg 2018;110:e333-8. 
Copyright 2019 BMJ Publishing Group. All rights reserved. For permission to reuse any of this content visit https://www.bmj.com/company/products-services/rights-and-licensing/permissions/

BMJ Case Report Fellows may re-use this article for personal use and teaching without any further permission.

Become a Fellow of BMJ Case Reports today and you can:

- Submit as many cases as you like

- Enjoy fast sympathetic peer review and rapid publication of accepted articles

Access all the published articles

Re-use any of the published material for personal use and teaching without further permission

For information on Institutional Fellowships contact consortiasales@bmjgroup.com

Visit casereports.bmj.com for more articles like this and to become a Fellow 